\title{
Towards a leadership programme for primary school principals as instructional leaders
}

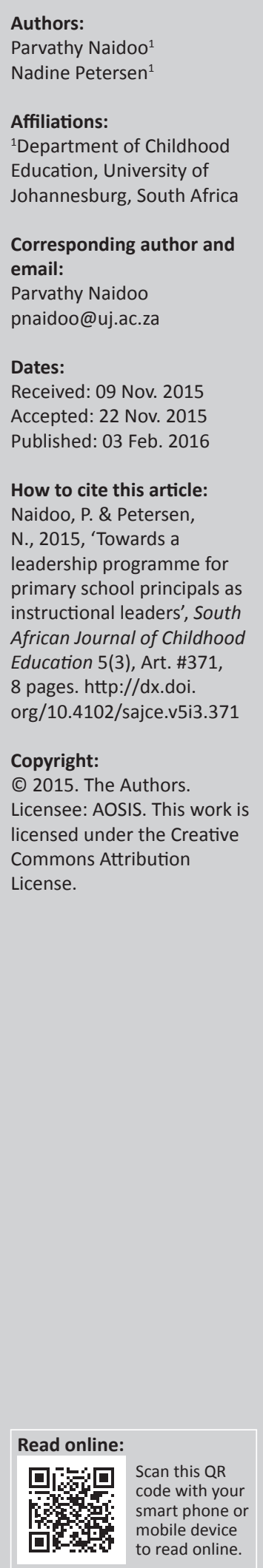

This study set out to explore primary school principals' instructional leadership. The study addressed a key issue in the school improvement literature, pertaining to the curriculum leadership of principals. The literature is not entirely clear about which leadership characteristic is more likely to produce the most favourable outcomes in terms of improved learner outcomes, in other words, how the curriculum has been implemented and how leadership in this regard has been effected. The article argues that robust training and development in instructional leadership practices become necessary to support school leaders in this regard. In South Africa, based on numerous reports of poor learner outcomes in schools, we question whether principals possess the necessary skills required to lead and manage curriculum in schools. In this article, the views of five principals, who have completed the Advanced Certificate in Education: School Leadership and Management (ACESLM) programme, are examined. Findings indicate that not all principals who participated in the study are fully conversant with their roles and responsibilities as instructional leaders. They mainly interpret their functions to be purely managerial and to be leaders and administrators of schools. Thus, whilst some understanding of instructional leadership was apparent in some of the principals' responses, it is the authors' views that ACESLM, as a leadership development programme, needs to be redesigned to include greater focus on instructional leadership.

\section{Introduction: Who are the leaders in schools?}

In a global educational environment, in which schooling systems are compared internationally and where there are increasing demands for the development of 21st-century skills, the schooling sector requires leaders who are deeply involved in the improvement of instruction and curriculum in schools. The Wallace Foundation (2008) argues:

Pick the right school leader and great teachers will come and stay. Pick the wrong one and, over time, good teachers leave, mediocre ones stay, and school gradually (or not so gradually) declines. (p. 3)

School principals are key to developing and maintaining successful, effective schools and education systems (Bush 2008; Hargreaves \& Fink 2006). However, in South Africa, many school principals operate without the necessary skills required to act effectively as leaders and managers of schools (Bush 2005:3) and, like managers in the corporate sector, they need to know and lead the 'core business'. In schools, the core activity is the fruitful implementation of the curriculum, including reliable systems of assessment of learners' educational outcomes and teachers' efficient and effective practice. Sustainable strategies for training and supporting school principals to achieve this are, according to Bush (2005), generally inadequate throughout Africa. Thus, whilst there is relative agreement in the leadership and management literature that professional development programmes are needed to ensure that school principals are fit for purpose (Blandford 1997:187; Moloi 2007:471; Prew 2007:447), there is far less clarity about which leadership characteristic is more likely to produce the most favourable outcomes in terms of leadership, management and organisation output towards improved learner outcomes - in other words, effective running of the core activity of schooling. There is even less consensus about how best to prepare school principals for the task of effective instructional leadership in schools.

What is clear is that school principals whose training was grounded in managerial models, very often struggle to acquire the knowledge and skills that they need to execute their functions as school heads and leaders of curriculum delivery. An area of school leadership development, according to Vick (2004:11-13), is the creation and sharing of a focused vision and mission for optimal learner performance. Vick claims that principals need to inform staff about performance expectations, including learner outcomes and then support them in the process to achieve these. This means that principals have to be well informed about the curriculum, teaching methods and assessment, new research on learning and so forth. 
Recent studies in South Africa (Bush 2013; Grobler 2013; Spaull 2011; Spaull \& Kotze 2015) report that learner achievement is most strongly connected with the type of school the learners attend. The more effectively the schools are run and the more instructional leadership is provided by school principals, the more likely the learners are to achieve. South African learners, despite being part of a relatively well-financed education system, are consistently performing poorly, according to three cross-country comparative studies (Taylor, van der Berg \& Mabogoane 2013). The Trends in Mathematics and Science Studies study conducted by the Human Science Research Council (2011), which tested Grade 8 mathematics and science; the Progress in International Reading Literacy study, conducted by Howie et al. (2011), which tests Grades 4 and 5 reading; as well as the Southern and Eastern Africa Consortium for Monitoring Education Quality project, the data of which were analysed by Spaull and Kotze (2015) and which tests Grade 6 mathematics, all provide evidence that South African learners are performing at significantly lower levels of competence than their counterparts in other developing nations.

As the foundation for learning successfully is established early on, we argue that the basis for improved learner achievement in the overall education system is in the improvement of the quality of education in primary schools. Key to this is equipping primary school principals as instructional leaders. To us, this means a focus on curriculum leadership, together with advanced instructional techniques for improved learner performance and overall school improvement. In our view, 21st-century principals are expected to become change agents who are deeply involved in the improvement of instruction and curriculum in schools.

The paper begins by providing a conceptualisation of instructional leadership as expounded in the literature. We then describe the various processes in the research design, followed by the findings. Thereafter, we present a discussion of the salient issues pertaining to instructional leadership. We conclude by providing recommendations derived from the findings.

\section{Instructional leadership: a core activity of a primary school principal}

We argue that schools are first and foremost about teachers teaching and learners learning: all other activities are secondary to these basic goals (Hoy \& Hoy 2003:1). Highperforming schools are characterised by strong leadership in this regard, by effective instructional practices and the capacity to improve learning. Sergiovanni (2009:57) and Mestry, Moonsammy-Koopasammy and Schmidt (2013:51) argue that this is possible only if school principals emphasise the building of an effective learning community within the school as well as creating caring education networks outside the school. This implies a strategic role for principals: as instructional leaders, they need to exhibit a clear sense of direction for their schools and possess the ability to prioritize what really matters in the school and the classroom in terms of the learners' work. As instructional leaders, principals primarily direct teaching for learning and support teachers and students in their work towards educational excellence (DeMatthews 2014:193).

This view of instructional leadership resonates with the educational leadership and management literature both internationally and in South Africa. For instance, DeMatthews (2014) defines instructional leadership as follows:

The leadership functions associated with teaching and learning, more specifically the duties and responsibilities principals need to perform each day to support teachers and learners towards educational excellence. In order to accomplish this, principals must create a safe, supportive and collaborative work environment. (p. 193)

The description is similar to that of Jita and Mokhele (2013) and Zepeda (2007), who are of the view that instructional leadership incorporates the process of creating and sustaining an environment in which the highly complex, socially textured tasks of effective schooling can take place. In agreement with the two above-mentioned studies, Horing and Loeb (2010) argue that the importance of school leaders hiring and assigning teachers to classrooms where ample opportunities are created for learner excellence by way of effective curriculum implementation are guided by the principal as a instructional leader.

However, despite relative consensus on a view of instructional leadership, agreement is always lacking amongst different educational management writers on which leadership traits are most likely to enable favourable learner outcomes. For example, Hargreaves and Fink (2006:233) and Hargreaves (2006:172) cite 10 characteristics for school and organisational success and improvement. These include the creation and preservation of sustainable learning in schools, the ability to secure success over time, sustaining the leadership of others, addressing issues of social justice, developing rather than depleting human and material resources, developing environmental diversity and capacity, and undertaking activist engagement with the environment. For the purposes of the paper, we align ourselves most closely with the ideas of Fullan (1997:153), who focuses on instruction and claims that leadership development must include meaningful engagement with ideas, materials and colleagues (both in and out of teaching) on intellectual, social and emotional levels. He places a great deal of emphasis on determining the context of teaching and on whether the experience of teachers is carefully accounted for. In this regard, Fullan's (1997:153-154) critical question of whether leadership development places classroom practice in the larger contexts of school practice and the educational careers of children is most pertinent.

Fullan (2003:5) advocates the notion of 'deep learning' in schools and argues that principals ought to create ample opportunities for deep learning to occur for learners. 
The learning opportunities should be directed by predetermined standards, which enhance development and growth. He advocates mentoring and coaching of both learners and staff as part of the learning process. This deep learning should be supported by school policies with established standards that facilitate individual learning and acceptable behaviour, which are central to creating good instructional leaders in schools. Furthermore, he proposes learning in context and 'system-ness', in which both individual learning and learning in context be integrated, by transferring transformed individuals into improved environments, where a synchronisation of the individual needs into the contextual needs is encouraged. Lastly, Fullan notes that principals are the ones who should improve working conditions and develop the teaching profession to attract new incumbents into the profession. For him, quality teachers will eventually become quality principals, as it is from teacher ranks that future leadership emerges. Lambert (2003:117) and Fullan (2003:2-5) share the view that principals as catalysts of sustainable leadership are able to create the environment where 'others' can follow as future leaders, thus adding value to succession planning in schools. The role of the school principal has thus shifted from a role dominated by a focus on leadership, management and administration to one focusing on instruction and systemic instruction capacity building, as explained by Grogan and Andrews (cited in Barber \& Meyerson 2007:3).

A lack of instructional leadership in primary schools can have serious consequences for the teachers and, ultimately, for the learners. If each teacher is left entirely to his or her own devices, it closes the door of collaborative work. We contend that the problems of curriculum implementation are really issues about how the leaders influence behaviour in subordinates to change the course of events to overcome resistance. Ultimately, effective leadership is crucial in implementing decisions successfully. Conversely, without good, effective leadership, organisational goals and learner outcomes may be scuppered (Arikewuyo 2007:1).

In South Africa, it has been found that principals are often appointed based on their teaching experience and performance in the classroom. We have also found, in our networks, that principals primarily describe their functions as administrative with some emphasis on learner welfare and discipline. This is in stark contrast to what Taylor et al. (2013:10) emphasize as the main role of a primary school principal, which is instructional leadership: ensuring that teachers attend and teach in class and that curriculum delivery is implemented successfully. According to Bush (2005:3), 'without the necessary skills, many principals are overwhelmed by the task', particularly as instructional leaders. Hoadley and Ward (2009:4), too, argue that training in financial management and instructional leadership is seriously lacking for principals in South Africa. Approximately 830 primary schools in Gauteng are classified as GPLMS schools (Gauteng Primary Literacy and Mathematics Strategy), where local district offices are required to put in place a carefully monitored programme to ensure curriculum coverage and delivery. This gives one some indication that there is insufficient instructional leadership capacity in many primary schools. The province has thus intervened in schools where instructional leadership is lacking, using a prescribed programme of teaching, assessment and materials to assist schools to make their work on par.

\section{The Advanced Certificate in Education, School Leadership and Management Programme}

Leadership development programmes for school principals can metaphorically be described as the oxygen which ensures that principals survive as educated and trained professionals, in order for them to improve their instructional leadership practices in the school (Jones et al. 1989:5). In recognition hereof, for almost a decade, South African principals and aspiring principals have had the option of enrolling in the Advanced Certificate in Education, School Leadership and Management, (ACESLM) programme as a leadership development programme. However, it is not a compulsory requirement for becoming a school principal.

The ACESLM was introduced in 2004 to both practicing and aspiring school principals in South Africa. The then Department of Education, South Africa (RSA DoE), proposed that the ACESLM be introduced as a leadership development programme for school principals. The programme is a 2-year, part-time, or a 1-year, full-time practice and competency-based programme, aimed at providing management and leadership development to school principals (RSA DoE 2008). The expectation regarding ACESLM is that the programme will lead to a sustainable positive change in leadership practice in public schools. The rationale for the programme is to provide an entry criterion to principalship, and as a professional, careerrelated qualification, it will be consistent with the job profile of school principals (RSA DoE 2008:4-5). The programme is delivered using the cohort model, which assures an interactive, supportive learning environment that provides ample opportunities for discussion and problem solving in teams.

Given the steady decline in learner achievement, measured in national and international tests, and the introduction of a leadership development programme to equip school principals as instructional leaders, we were interested in gaining some insights into how school principals who have been through such a programme view their effectiveness as instructional leaders. Whilst this paper is not intended to be an evaluation of the effectiveness of the ACESLM, it may shed light on the programme's influence in equipping principals as instructional leaders.

We addressed the following research question: how do primary school principals, who have been part of the leadership development programme, ACESLM, view their roles as instructional leaders? Underlying this question is an assumption that the programme will, in some way, influence their discourse. 


\section{The inquiry \\ Participants and data collection}

This study of principals as instructional leaders in primary schools is based on individual interviews with five primary school principals who were part of a larger study on the impact of a leadership development programme (ACESLM) on school principals' sustainability of leadership practices in primary schools. Access to the participants' schools was facilitated through the local district education office, and then, the school principals were approached directly. The interviews were conducted at the schools, where the principals' work, at a time designated by the participants so as not to disrupt school activities. The first author, having been a principal of a primary school herself, conducted the interviews. We believed that the participants would be more comfortable sharing information about their leadership practices with her, given their shared backgrounds. We were interested in gaining an understanding of how each school principal had viewed his or her role as instructional leader in their own words (Patton 2002:47). Throughout each interview, the interviewer made notes including key words and phrases and in some cases included short quotes and multiple sentences from participants (Creswell 2009a:229).

All the principals had obtained, at least a diploma in primary school education or a Bachelor of Education in primary school education degree and had completed the Advanced Certificate in Education, Leadership and Management certificate. The principals had two or more years of instructional leadership practice. We reasoned that changes in leadership practices would only be visible after 2 years, a period which would also allow us to see if the influence of the training had persisted. One female and four male principals were interviewed from schools, which are categorised into one of the five quintiles aligned with a poverty index, according to the National Norm and Standards for School Funding (Education Labour Relations Council 2003:B52).The classification index in turn determines the level of funding granted by the Education Department. Quintile one schools are no-fee schools and receive a 100\% funding per learner, whilst quintile five schools receive the least funding as these schools are perceived to be affluent and well resourced.

\section{Data analysis}

Interviews lasted between 60 and $120 \mathrm{~min}$ and were transcribed for ease of analysis. We named the participants A, B, C, D and E to distinguish the five research sites. The transcripts were read through a number of times by the first author to obtain a general sense of the data (Creswell 2009b) whilst checking for accuracy in transcription to enable a summary to be composed of the key issues they contained. Thereafter, each of us worked individually with the transcriptions first, before comparing our interpretations and analysis. It was here that the first author's familiarity with the context and participants was useful in providing context to specific aspects of the interviews. For the analysis of individual interviews, we used a form of open coding led by broad descriptors of instructional leadership in the literature. We first identified smaller units of text that could stand on their own meaningfully in line with procedures associated with qualitative content analysis (Babbie \& Mouton 2008; Henning, van Rensburg \& Smit 2004; Merriam 2002). For instance, from the interview with Participant B: 'what I learnt ... it's important for school managers to know what is happening in the classroom' was extracted and labelled as 'conceptions of instructional leadership'. Likewise from Participant $C$, the following was extracted 'you are managing teaching and learning' was labelled in the same way. We colour-coded similar occurrences across the set of transcripts and began to link comparable ideas, views, thoughts and concepts. Thereafter, we were able to identify common elements that were apparent across interviews and link them to form the findings.

\section{Data presentation and findings}

Of the five participants, only three described their roles as instructional leaders using some of the descriptors associated with terms in the literature (Arikewuyo 2007; Bush 2008; Du Plessis, Conley \& Du Plessis 2007; Hallinger 2009). These participants mainly discussed their instructional leadership functions in terms of leading and managing staff, with some reference to teaching and promoting learning, whilst making little explicit mention of curriculum leadership. The two other principals refer to their instructional leadership roles in purely managerial terms, with a strong emphasis on administration. The issue of leading the teachers to work with the curriculum was not prominent in the discourse.

\section{Curriculum instruction: leading and monitoring teaching processes towards improved students' learning}

The feedback from participants A, B and C, whilst not always explicitly mentioning curriculum leadership, makes reference to their leadership and involvement in teaching processes that directly impact learner outcomes. For instance, Participant A reported that 'principals play an important role regarding curriculum implementation' and 'you play an important role to lead as curriculum organiser, with your deputies and heads of department'. He acknowledges that his approach of 'creating ownership' and motivating staff to take development opportunities has led to him 'having a teaching team that is excellent'. Participant B also noted that his task was to 'lead as a curriculum organiser'. One way in which he does so is by 'providing extrinsic motivation for his staff ... awarding their teaching ... efforts by acknowledging them at school functions'. This, he believes, encourages his staff to strive for better student results/outcomes. Disappointingly, principals D and E excluded curriculum leadership from 
descriptions of their set of responsibilities. For instance, principal D said his role was to take care of 'management issues', whilst the 'role of the deputy principal (was) to deal with issues related to the curriculum'. Participant E too saw her role as 'dealing with school governors' and the deputy principal's role as 'dealing with curriculum matters'.

There was much emphasis in the first three interviews on encouraging effective teaching towards improving learners' outcomes. In this respect, principals talked about closely monitoring teaching activities and providing good examples of effective teaching for staff. For instance, principal B noted: 'our core business is teaching and learning ... we need to know what happens in the classroom ... and be an expert in the classroom....'

Most of the principals were clear that as instructional leaders, they required effective strategies for monitoring teaching activities. One way in which participants A, B and C described this in the interviews was through 'managing activities associated with teaching and learning' (C) and managing detailed discussions of lesson outlines and plans 'to ensure successful (curriculum) delivery' (A). All participants said they lead by example as evidence by the following quote: '...the school management team also plans and does lesson plans ... me too, I also do lesson plans' (C).

Principal B and Principal A too mentioned that they submit lesson plan, work schedules and progress files for monitoring and evaluation to the respective heads of department in their schools. In fact, Participant A noted, 'I Iead by example, here is my file' and produced, during the interview, a welldocumented file with various teaching artefacts for scrutiny. Participant $C$ was clear that a strong emphasis on 'managing teaching' will lead to 'teachers and learners committing to the learning process' and that his responsibility was to put his knowledge 'into practice by developing others in teaching ...'.

Participant D on the other hand did not see this as his role. He expressed the view that:

'teachers are adults who are getting paid for a job' and that it meant that they should be 'well prepared, come to class and teach so that learners will also become eager to come to class and learn'.

He indicated that it was not his responsibility to monitor teaching activities:

'I strongly believe that I need not motivate anybody" and "I also don't have the capacity and time to go around telling staff what to do and how to do it'.

\section{The value of ACESLM from the perspectives of the participants}

All participants indicated that the ACESLM programme, and in particular, the module 'Lead and Manage people' was useful to their development as leaders. This is, as Msila
(2010) argues, an aspect of effective instructional leadership required by principals as school leaders and managers.

A first aspect of the ACE highlighted in the interviews was learning about leading others. Participant B describes this as follows:

'you start realising the styles of leadership practices expected from you as a manager and a leader through this course ... [it] changed my management and leadership style. Participant $C$ had a similar view: 'I think it has helped me to improve my management and my leadership skills' and 'this course [helps] developing one's own teaching skills and leadership skills'.

Of the five participants, only A linked his learning about leadership styles to instructional leadership:

'you have to ... look at the different leadership styles ... which leadership style and communication approach will support and encourage teaching and learning, when dealing with diverse staff'

Participants A, B and C spoke extensively of 'effective team building and teamwork', which in their views contribute meaningfully to good instructional leadership practices. Team building as an aspect of instructional leadership is discussed in the literature. Kouzes and Posner (2001) note that effective instructional leaders encourage and accommodate collaborative leadership and shared decision making. This, they argue, improves relationships between various stakeholders, which leads to a stable culture of teaching in schools. Participant A reported that the value of teamwork was to encourage 'staff (to) make sacrifices after hours ... to reach the school's vision'. Participant C's utterances also align with this view:

'... as a principal you have to lead firstly, you have to be humble and you must be transparent and honest, trustworthy and be a role model, people must see you as an example at school. Then it becomes easy to follow you as a leader and as a principal. You must not dictate to people ... it must come from them ... and together we must say this is the vision of the school, and that is to teach'.

On the contrary, there were few references to how the course impacted the participants' views of curriculum leadership as a component of instructional leadership. However, the data from participants A, B, C and E do make reference to its influence on the creation of management plans and schedules for monitoring the school curriculum. Two specific references to curriculum and instruction are apparent in the comments of Participant A, who refers to learning about 'good control mechanisms in managing learner-teacher support material (LTSM), which is crucial to effective teaching and learning' and Participant B who says that he 'become more involved in curriculum issues than before the programme'. Principal D, a principal of many years, spoke of 'learning about financial and project management' and how to act as a consultative, involving leader who gains his staff's trust. However, his responses excluded any mention of his role in curriculum and instruction matters in the school. He indicated that was the responsibility of the deputy principal in his school. 
A third aspect of the programme that all participants seemed to value was the research component, which was to be undertaken at their respective work sites. All reported that these projects were to the advantage of improving teaching and pupils' learning in their own schools and had some benefit for the wider school community. Examples include Participant A, who heads an advocacy campaign for E-Learning in the neighbouring schools and participates as a presenter in the district office-lead South African Administration System programme training through the district office. His participation in this programme is in the area of strengthening school leadership and curriculum delivery practices. In his words, the ACESLM has 'given him this opportunity to empower others in teaching and learning'.

Participants B and C describe how their projects encouraged team work between the school and community. For Participant $\mathrm{C}$, an intervention he initiated in his network was directly related to curriculum leadership. He mentioned his role in a 'crisis team' who spent 'long hours with other principals, working out strategies to address curriculum shortages to catch up with lessons' that were missed during the union strike, which lasted for many weeks. He attributes his success in this intervention to skills learnt in the ACESLM programme.

Participant B, a self-proclaimed introvert, ascribes his new professional relationship with other principals, and their goal of improving academic excellence in their schools, to the formation of a cohort group in the programme. He also established a library at his school which was then available for the surrounding community as well as local preschools and learners in other schools. Participant B attributes this intervention to the ACESLM programme.

Even Participant D who reported that the ACESLM programme had merely 'served as a refresher for the basic tasks of a principal' and that he 'had not learned anything new' noted that as principals with many years of experience 'we knew about things that were supposed to have been done, and we overlooked it. I think we were in a comfort zone where we forgot the basics and this course reminded us of the basics that we needed to keep in place all the time'. He agreed that the 'ACESLM assisted in forming a group that was not in existence before', and resulted in a working relationship with his peers.

\section{Discussion and conclusion: is the ACESLM programme responding to the core activity of schools?}

From the data that we analysed, it is evident that school principals hardly see themselves as 'curriculum people', but do view their work as that of a manager of an organisation. There is, in these data, little evidence that the principal task of a principal is to ensure that the core activity of a school remains its core activity, performed by professionals who know the curriculum, including its contents and assessment and teaching strategies. Perhaps this is one of the (many) reasons not enough learning is taking place in the primary schools of the country, where the foundation for further learning is laid.

It is widely recognised that educational outcomes for South African children are contingent upon the creation of a firm knowledge base in the primary school (Taylor et al. 2013). The efficacy of primary school teachers is thus key to achieving this goal. But what exactly does this encompass? Our view is first that primary school teachers need to know young children and how to teach them effectively, taking cognizance of children's development in tandem with teachers' own growing pedagogical knowledge. This implies a solid repertoire of teaching strategies deeply rooted in the knowledge of how children develop over time in order to translate the primary school curriculum content effectively to child learning. This view is also held by Sahlberg (2011), who argues that in Finland, importance of early education is evident in the very high completion rate $(99 \%)$ of basic education by the age of 16 .

We would argue that the responsibility for classroom learning rests with the school principal, who has to ensure that this occurs by managing and leading the schools' instructional programme. The responses of the first three participants reflect attention to curriculum matters and teaching processes that directly impact learner outcomes. Both the content and discourse of their responses speak to them taking on the role of 'lead learners' (Mednick 2003) through engagement with teachers to improve student outcomes. In addition, reports by principals A, B and C of leading by example and complying with the same directives expected of their staff speak volumes for a hands-on approach to guiding pedagogical choices. This is in line with the recommendations by Hallinger and Murphy (1986) that effective school principals need to take leadership of managing the instructional programme. Participants D and E on the other hand delegate this responsibility to other school managers with no indication of how they monitor these aspects in their schools. In our view, this is detrimental to improving learner outcomes: divorcing leadership for curriculum oversight from their roles as school managers, risks devaluing curriculum coverage, minimises the importance of promoting effective instructional strategies and diminishes the principals' ability to effect positive change in the school.

Most telling from all the participants' responses is that there was no explicit mention of needing to develop teachers' knowledge of learners and the best methods to teach them effectively. Thus, although their discourse points to an emphasis on some aspects of curriculum leadership, it is a matter of concern that there seems to be little cognisance of the principal's role in leading initiatives for teachers to learn how to integrate knowledge of the young learner with pedagogical strategies and the curriculum content. It is 
possible that the principals do not see this connection clearly and/or that insufficient attention is given to this integration in the ACESLM. In our experience of the early teacher education programmes from which many of the current primary school principals graduated, this was also not likely to have been emphasised.

As part of managing the instructional programme, principals also need to collect and analyse data (assessments) towards fostering school improvement (Hallinger 2005; Mendels 2012). None of the participants focused on this aspect in the interviews. We are concerned that if learner assessment data are ignored or underestimated, then school principals may not be able to identify where (and with which teachers and classes) instructional strategies are failing and they may neglect to intervene when specific teachers' strategies are not resulting in the desired learner outcomes. Development plans towards improvement may then not target the specific individuals or curriculum aspects in a focused fashion. To us, it begs the question of whether principals are au fait with the best possible methods for gathering the required data to measure school improvement, the techniques for analysis required and how to direct targeted development towards improvement.

A third implication of the findings that concerns us is the absence of issues of educational law, legislation, policy and procedures from the principals' responses. These aspects are directly tied to oversight of effective curriculum implementation. For instance, at a very basic level curriculum implementation is governed by policy and procedures stipulated by the DoE. As instructional leaders, any noncompliance with the implementation of RSA DoE curriculum is a very serious issue. None of the participants made any mention of this, despite the ACESLM programme comprising a module solely on Educational Law and Policy. Our interpretation hereof is that participants may not be able to link the various modules of their training programme to one of their main responsibilities, that of managing the instructional programme through monitoring curriculum interpretation and coverage or that the ACESLM training does not provide sufficient integration of its various modules for principals to see how these are connected.

The second element for discussion is how principals as instructional leaders work with and through others to create positive and engaging school climate. This is a second crucial element of the framework for instructional leadership explained by Hallinger and Murphy (1986): creating a positive school environment. Thus, when principals publically advocate the schools' vision, mission and academic goals, they become the leaders of learning in their respective schools (Gray 2011; Vick 2004). The research literature in this area indicates that principals should be able to foster collegial relationships amongst teachers, and we would argue, particularly around curricular issues (DeMatthews 2014; Mitchell \& Castle 2005; Ylimaki \& Jacobson 2013). The findings of our research again reveal that this is prevalent in the responses of the first three principals. Principal B spoke about acknowledging teachers' efforts publically, whilst principal A referred to his attempts at building an effective school management team and his discussions with teachers about lesson plans and outlines, initiatives shared by principal $C$. These three principals specifically attributed much of this to the ACESLM programme, with specific mention of its contribution to helping them develop as leaders, capable of managing school finances, team building and the advancement in developing LTSM. Here even principal D's responses included reference to the value of the leadership programme.

Where the programme seems to have been most beneficial for four of the five principals (A, B, C and D) was in promoting collaborative networks with other principals in the areas where their schools are situated. They spoke about creating and sharing resources with neighbouring schools and communities, finding solutions to challenges and resolving conflict matters through discussion networks in the same areas. It appears as if the action research projects in the ACESLM are beneficial for developing the leadership skills of these principals for the benefit of a network of schools as well as the wider community. On the contrary, Participant E did not attribute any value to the programme and seemed to be most focused on the more perfunctory aspects of being a school principal, such as complying with administration, regulatory and reporting tasks.

The authors agree that schools cannot be places where 'big' people who are learned teach 'little' people who are learners (Barth, cited in Naidu et al. 2008:94). Schools should be places where both adults and young people discover the joy of learning and this is only possible if the principal assumes the role of lead instructional learner, who fosters an organisational culture that embraces continuous learning by all stakeholders.

Whilst there is evidence of the ACESLM influencing the instructional leadership role of the majority of the participants, we argue, based on the findings of this small-scale study, that perhaps the full range of leadership roles for a school principal is not sufficiently addressed in the programme. We recommend that future leadership development programmes in South Africa, include additionally, a module on instructional leadership with various assessment fundamentals built into it. The content of the module to prepare principals as instructional leaders should focus on extrapolating the functions required of effective instructional leaders. The functions are the development of the academic vision and mission of the school pointed out by Hallinger and Murphy (1986) and the creation of an environment conducive to learning (Jenkins 2009; Mendels 2012; Mestry et al. 2013), which promotes and sustains excellent learner outcomes. Effective instructional leaders coordinate curriculum whilst monitoring and evaluating learner outcomes and ensure that teacher mentoring and development programmes are in place according to Horing and Loeb (2010) and Grobler (2013). If we are to begin improving educational outcomes in later years in the South African school system, 
then particular attention should be made to how the various facets of instructional leadership in primary schools will direct effective teaching towards improved learner outcomes.

\section{Acknowledgements}

As a recipient of the Next Generation Scholarship, author Parvathy Naidoo acknowledges University of Johannesburg in funding her PhD study, from which this article emanates.

\section{Competing interests}

The authors declare that they have no financial or personal relationships, which may have inappropriately influenced them in writing this article.

\section{Authors' contributions}

P.N. (University of Johannesburg) and N.P. (University of Johannesburg) completed equally to the writing of this article.

\section{References}

Arikewuyo, M.O., 2007, 'Teachers' perceptions of principals' leadership capacities in Nigeria', Academic Leadership Journal 5(3), 1-8.

Babbie, E. \& Mouton, J., 2008, The practice of social research, South African edition, Oxford University Press, Cape Town.

Barber, M.E. \& Meyerson, D., 2007, 'School leadership study developing successful principals. The Gendering of School Leadership: "Reconstructuring the Principalship"', Paper presented at Stanford University, Stanford.

Blandford, S., 1997, Middle management in schools: How to harmonise managing and teaching for an effective school, Pitman Publishers, London.

Bush, T., 2005, 'Preparation for school leadership in the 21st century: International perspectives', Keynote paper at First Head Research Conference, Oslo.

Bush, T., 2008, Leadership and management development in education, Sage Publishers, London.

Bush, T., 2013, 'Instructional leadership and leadership for learning: Global and South African perspectives', Education as Change 17(1), 5-20.

Creswell, J.W., 2009a, Research design: Qualitative, quantitative and mixed methods approaches, 3rd edn., Sage Publications, Los Angeles.

Creswell, J.W., 2009b, Educational research: Planning, conducting, and evaluating quantitative and qualitative research, 3rd edn., Pearson Education International, Upper Saddle River.

DeMatthews, D.E., 2014, 'How to improve curriculum leadership: Integrating Leadership Theory and Management Strategies', The Clearing House: A Journal of Educational Strategies, Issues and Ideas 87(5), 192-196.

Du Plessis, P., Conley, L.N. \& Du Plessis, E., 2007, Teaching and learning in South African Schools, Van Schaik Publishers, Pretoria.

Education Labour Relations Council, 2003, Policy Handbook for Educators, viewed n.d, from http://www.education.gov.za

Fullan, M., 1997, The new meaning of educational change, 2nd edn., Teacher's College Press, London.

Fullan, M., 2003, 'Leadership and sustainability. Plaintalk', Newspaper for the Center for Development and Learning 8(2), 1-5.

Gray, D., 2011, 'A new look at instructional leadership', International Journal of Educational Leadership Preparation 4(1), viewed n.d. from http://cnx.org /content/m19557/latest/

Grobler, B., 2013, 'The school principal as Instructional Leader: A structural equation Model', Education as Change 17(1), 177-199.

Hallinger, P., 2005, 'Instructional leadership and the School Principal: A passing fancy that Refuses to Fade Away', Leadership and Policy in Schools 4(1), 1-20.

Hallinger, P., 2009, Leadership for 21st century schools: From instructional leadership to leadership for learning, The Hong Kong Institute of Education, Hong Kong, China.

Hallinger, P. \& Murphy, J., 1986, Instructional Leadership in effective schools. US Department of Education. Educational Resources Information Center. ERIC.
Hargreaves, A., 2006, 'Sustainable leadership', in B. Beatty, B. Caldwell, J. Davies, T.E. Deal, A. Hargreaves, G.C. Hentschenke et al. (eds.). The essentials of schoo leadership, pp. 172-189. Edited by Davies, B. Sage Publications, Thousand Oaks.

Hargreaves, A. \& Fink, D., 2006, Sustainable leadership, Jossey- Bass, San Francisco.

Henning, E., van Rensburg, W. \& Smit, B., 2004, Finding your way in qualitative research, Van Schaik Publishers, Pretoria.

Hoadley, U. \& Ward, C., 2009, Managing to learn: Instructional leadership in South African schools, HSRC Press, Cape Town.

Horing, E. \& Loeb, S., 2010, 'New thinking about instructional leadership', Kappanmagazine.org 92(3), 66-69.

Howie, S., van Staden, S., Tshele, M., Dowse, C. \& Zimmerman, L., 2011, Progress in international reading literacy studies, South African children's literacy achievement report, Centre for Evaluation and Assessment, University of Pretoria, Pretoria.

Hoy, A.W. \& Hoy, W.K., 2003, Instructional leadership, a learning- centred guide, A Pearson Education Company, Boston.

Human Science Research Council, 2011, Highlights from TIMMS, The South African Perspective.

Jenkins, B., 2009, What it takes to be an Instructional Leader, viewed n.d., from www.elead.org/resources/resources/resources.asp?ResourcesID=14

Jita, L.C. \& Mokhele, M.L., 2013, 'The role of lead teachers in Instructional leadership: A case study of environmental learning in South Africa', Education as Change 17(1), 123-135

Jones, K., Plano Clark, J., Figg, G., Howarth, S. \& Reid, K., 1989, Staff Development in primary schools. Blackwell Publishers, Oxford.

Kouzes, J.M. \& Posner, B.Z., 2001, in W. Bennis, G.M. Spreitzer \& T.G. Cummings (eds.), Bringing leadership lessons from the past into the future, Jossey-Bass, San Francisco.

Lambert, L., 2003, Leadership capacity for lasting school improvement, ASCD Publications, Alexandria.

Mednick, A., 2003, 'The principal's new role: Creating a community of leaders', Center for Collaborative Education 4(1), 1-13.

Mendels, P., 2012, 'The effective principal', Feature: Leadership 33(1), 54-58.

Merriam, S.B., 2002, Qualitative research in practice: Examples for discussion and analysis. Jossey-Bass, San Francisco.

Mestry, R., Moonsammy-Koopasammy, I. \& Schmidt, M., 2013, 'The instructional leadership role of primary school principals', Education as Change 17(1), 49-64.

Mitchell, C. \& Castle, J.B., 2005, 'The instructional role of elementary school principals', Canadian Journal of Education 28(3), 409-433.

Moloi, K., 2007, 'An overview of education management in South Africa', South African Journal of Education 27(3), 463-476.

Msila, V., 2010, 'Rural school principal's quest for effectiveness: Lessons from the field', Journal of Education 48, 169-189.

Naidu, N., Joubert, R., Mestry, R., Mosoge, J. \& Ngcobo, T., 2008, Education management and leadership: A South African perspective. Oxford University Press, South Africa.

Patton, M.Q., 2002, Qualitative research evaluation methods, 3rd edn., Sage, Thousand Oaks.

Prew, M., 2007, 'Successful principals: Why some schools succeed and others struggle when faced with innovation and transformation', South African Journal of Education 27(3), 447-462.

Republic of South Africa, Department of Education (RSA DoE), 2008, Advanced Certificate: Education (School Management and Leadership), NQF, Level 6, Course Outline, Ver. 6, Government Printer, Pretoria.

Sahlberg, P., 2011, 'Developing effective teachers and school leaders: The case of Finland', in Darling- Hammond \& Rothman (eds.), Teacher and leader effectiveness in high performing education systems, pp. 13-21, Alliance for Excellent Education, Washington, DC.

Sergiovanni, T.J., 2009, The principalship: A reflective practice perspective, 6th edn. Allyn \& Bacon Publishers, Boston.

Spaull, N.A., 2011, Preliminary Analysis of SACMEQ 111, South Africa, Working Papers $11 / 11$, Stellenbosch.

Spaull, N.A. \& Kotze, J., 2015, 'Starting behind and staying behind in South Africa. The case of insurmountable deficits in learning mathematics', International Journal of Educational Development 41(2005), 13-24.

Taylor, N., Van der Berg, S. \& Mabogoane, T., 2013, 'Context, theory, design', in N. Taylor, S. Van der Berg \& T. Mabogoane (eds.), Creating effective schools, pp. $1-30$, Pearson, Cape Town.

Vick, R.C., 2004, The use of SREB leadership development framework in preservice preparation programs: A qualitative study. Department of Educational Leadership and Policy Analysis, East Tennessee State University, viewed n.d. from http://etd-submit.etsu.edu/etd/theses/available/etd-0809104-151312 /unrestricted/VickR081904f.pdf

Wallace Foundation, 2008, Becoming a leader, preparing school principals for today's schools, Task Report, New York.

Ylimaki, R. \& Jacobson, S., 2013, 'School leadership practice and preparation', Journa of Educational Administration 51(1), 6-23.

Zepeda, S.J., 2007, The Principal as Instructional Leader. A handbook for Supervisors, 2nd edn., Eye on Education Publishers, New York. 